\title{
ORANG MUDA BICARA TENTANG PENGARUH KOMUNIKASI BERBASIS KOMPUTER TERHADAP KEHIDUPAN UMAT BERIMAN
}

\author{
Yap Fu Lan
}

\begin{abstract}
:
This research explores young people's perspectives of the use of computer based communication and its influences to the meaning of human communication and to the life of religious communities. The method occupies focus group discussion, plain analysis, and narrative description. The young people's speaking content three paradoxical pictures: extending human communication in many ways, computer based communication dissolves the personal aspect of it in a certain way; promoting virtual presence as the virtue of contemporary human communication, computer based communication corrupts the communal dimension of religious life; and giving hope to interreligious dialogue, computer based communication brings forth the concerns of religious leadership.
\end{abstract}

\section{Kata-kata Kunci:}

Komunikasis berbasis komputer, orang muda, personal, virtual, komunal, dialog, komunitas agama.

\section{PENDAHULUAN}

\section{1. Latar Belakang Masalah}

Komunikasi manusia saat ini berkembang pesat tanpa terhalang lagi oleh batas-batas waktu dan teritori berkat penemuan dan perkembangan teknologi komunikasi berbasis komputer, khususnya telepon selular dan internet (Ruben dan Lea, 2006:78). Banyak orang yakin, ini merupakan sebuah harapan baru bagi pembangunan relasi antar manusia di tingkat lokal maupun global.

Gereja Katolik mengakui perkembangan komunikasi sosial dan sumbangannya bagi pengembangan hidup masyarakat dunia. Pesan-pesan apostolik untuk Hari Komunikasi se-Dunia, sejak 1967 hingga sekarang, ikut memperkaya wawasan katolik mengenai komunikasi manusia. Gereja memberikan dorongan kepada anggotaanggotanya untuk memanfaatkan media komunikasi "untuk menyegarkan hati dan mengembangkan budi, dan untuk menyiarkan serta memantapkan Kerajaan Allah" (Inter Mirifica, 2). Namun, Gereja juga menunjukkan sikap waspada terhadap penyalahgunaan dan pengaruh negatif media komunikasi.

Kenyataannya, fenomena media komunikasi berbasis komputer memang memiliki wajah lain yang tidak secerah gambaran kecanggihannya. Sisi buram itu terlihat antara lain dalam kecen- derungan orang untuk mengisolasi diri dari lingkungan sekitarnya ketika ia berkomunikasi dengan yang lain di dunia virtual dengan gadgetgadget milik pribadi. Selain itu, keterbukaan ruang virtual memungkinkan penyebaran beragam informasi, pemikiran, dan ekspresi-ekspresi manusia yang bersifat destruktif pula. Memandang sisi buram ini, peneliti mempertanyakan pengaruh komunikasi berbasis komputer terhadap makna komunikasi manusia dan kehidupan komunitas beragama.

\section{2. Metodologi Penelitian}

Penelitian ini mengikuti pola eksplorasi teologi praksis (practical theology) yang bersifat kualitatif. Pengumpulan pandangan kaum muda dilakukan melalui diskusi kelompok yang berfokus pada pengaruh komunikasi berbasis komputer terhadap makna komunikasi manusia, nilai komunal di dalam komunitas beragama, dan relasi antar komunitas beragama. Diskusi melibatkan 45 mahasiswa dari berbagai fakultas di Unika Atma Jaya. Mereka terbagi menjadi lima kelompok, dan melakukan diskusi secara terpisah. Ide-ide pokok yang muncul di dalam kelima diskusi didialogkan satu dengan yang 
lain dan dengan agasan-gagasan mengenai komunikasi berbasis komputer dari sumber-sumber gerejani maupun ilmu sosial. Hasilnya dipaparkan secara naratif di dalam tiga bagian, yakni: (1) komunikasi antar manusia, (2) nilai komunal dalam kehidupan beriman, dan (3) harapan bagi dialog antar agama.'

\section{KOMUNIKASI ANTAR MANUSIA}

\section{1. 'Hirarki' Pengertian Komunikasi}

Diskusi mengenai makna komunikasi manusia mengemukakan semacam hirarki pengertian komunikasi. Pada strata pertama, komunikasi dipahami sebagai aktivitas satu arah, antara lain: mengungkapkan keinginan, mempengaruhi orang lain, menjelaskan sesuatu/pendapat, menyampaikan pesan, menyalurkan aspirasi, pikiran, dan perasaan, dan memindahkan informasi. Pada tingkat ini, fokus utama adalah kehendak si komunikan/pihak pertama. Pada strata kedua, komunikasi dilihat sebagai aktivitas yang bersifat mutual, yakni: menjaga relasi dan aktivitas sosial, berinteraksi dengan orang lain, dan mengetahui keinginan satu sama lain. Dalam konteks mutualisma ini, pikiran, pendapat, dan perasaan pihak lain juga penting. Maka, di dalam komunikasi, "mendengarkan" bernilai sama penting dengan "menyampaikan". Dalam konteks ini pula, komunikasi dinyatakan sebagai "pertukaran simbol" (Verbatim FGD III, 46). Pertukaran simbol menjadikan komunikasi sebagai sharing pengalaman, sebab makna simbol ditemukan di dalam dan melalui pengalaman. (Tubbs and Moss, 2008:7; Ruben and Lea, 2006:79-80.)

Pengertian komunikasi pada strata ketiga nampak dalam pernyataan Eni ${ }^{2}$ (FKIP):

Komunikasi [...] merupakan jembatan [...] untuk berelasi, atau media berelasi. Tapi, relasi itu bukan [hanya] ke sesama, atau dari manusia satu ke manusia yang lain, tapi juga manusia ke dalam dirinya sendiri. Jadi manusia juga berkomunikasi dengan dirinya dan mungkin juga berkomunikasi dengan Tuhan. (Verbatim FGD II, no. 17)

Pernyataan ini sangat relevan dengan pesan Paus Benediktus XVI untuk Hari Komunikasi Sedunia ke 46, tahun 2012, bertajuk: Silence and Word: Path of Evangelization. (www. vatican.va, diakses pada 18 Februari 2012) Paus mengingatkan umat beriman bahwa komunikasi memiliki dua aspek, yakni: keheningan (silence) dan kata/ucapan (word). Komunikasi bermakna dan bernilai hanya bila keduanya hadir dalam harmoni. Keheningan merupakan sumber kata/ ucapan. Keheningan memungkinkan seseorang mendengarkan dan mengenali dirinya, juga mendengarkan dan memahami orang lain. Keheningan juga memungkinkan seseorang berbicara dengan Tuhan. ${ }^{3}$

\section{2. Dua Wajah Komunikasi Berbasis Komputer}

Topik relasi dengan diri sendiri dan dengan sesama muncul kembali dalam diskusi mengenai isu-isu dalam komunikasi berbasis komputer. Teknologi komunikasi berbasis komputer memungkinkan komunikasi antar manusia tanpa perjumpaan face-to-face (Ruben and Lea, 2006:78). Teknologi komunikasi berbasis komputer mempermudah dan mempercepat penyampaian pesan dan informasi. Jarak geografis bukan lagi penghalang untuk menjaga kekerapan berkomunikasi.

Beberapa narasumber menunjukkan pengalaman-pengalaman mereka berkomunikasi untuk memelihara persahabatan dengan temanteman yang melanjutkan studi ke luar negeri. Berkat internet, teman-teman ini juga dapat berkomunikasi secara intensif dengan keluarga mereka masing-masing. Berkat teknologi pula, komunikasi antar manusia saat ini berkembang pesat. Rudy (FT) dan Ana (FPsi) bahkan berkeyakinan bahwa jejaring komunikasi yang terbangun secara luas, seperti Facebook dan Twitter, dapat menjadi kekuatan massa untuk meruntuhkan kekuatan-kekuatan hukum dan pemerintahan, juga untuk membangun gerakan sosial-kemanusiaan secara nasional (Verbatim FGD I, 22; Verbatim FGD III, 83).

Para narasumber pun melihat sisi-sisi negatif komunikasi berbasis komputer. Pertama, nilai personal-interpersonal dalam komunikasi antar manusia berkurang. Jeni (FK) memberikan contoh: ketika seorang teman curhat kepadanya melalui media komunikasi berbasis komputer, ia tidak bisa memegang tangan si teman untuk menghibur atau meneguhkannya. Bagi Jeni, physical touch dibutuhkan untuk melengkapi kata-kata penghiburan (Verbatim FGD IV, 19). Gina meragukan kemurnian atau kejujuran ekspresi-ekspresi yang tertuang melalui media komunikasi berbasis komputer (Verbatim FGD 
IV, 29). Bagi Brigita (FKIP), kata maupun ikon yang digunakan dalam media tersebut tidak dapat merepresentasikan situasi emosional yang sesungguhnya (Verbatim FGD II, 61). Timotius (FKIP) menilai bahwa dengan meninggalkan komunikasi face-to-face, orang membangun "relasi semu" (Verbatim FGD II, 66). Di dalam relasi semu itu, unsur paling penting dalam komunikasi bukan person/pribadi manusia melainkan media komputer.

Kedua, alih-alih meningkatkan intensitas dan kualitas relasi antar manusia, ruang virtual juga dapat menjadi ruang sindir-menyindir, hinamenghina, caci-mencaci, bahkan tipu-menipu. Ruang ini dirasakan lebih 'aman' sebab individu dapat tampil anonim, tanpa identitas, atau dengan identitas palsu. Selain itu, menurut beberapa narasumber, komunikasi berbasis komputer membuka kemungkinan lebih besar bagi kekeliruan interpretasi daripada komunikasi langsung. Bagaimana pun, dalam keyakinan para narasumber ini, komunikasi langsung lebih efektif untuk menyelesaikan masalah-masalah akibat keliru interpretasi atau salah paham. Isuisu ini berkembang di dalam diskusi mengenai dialog antar agama.

Rudy (FT), Fifi (F), dan Gina (FK) melihat sisi negatif lain yang berkaitan dengan isu antar generasi. Bagi Rudy, kesenjangan antar generasi dapat menjadi dasar perbedaan interpretasi yang berkaitan dengan norma. Misalnya, penyebaran undangan pernikahan via surat elektronik atau e-mail. Orang-orang muda mungkin lebih toleran daripada orang-orang tua. Sementara generasi muda menganggap undangan via email sebagai wajar, generasi tua mungkin memperhitungkannya sebagai tindakan "tidak sopan" (Verbatim FGD I, 37). Apalagi, menurut Fif, banyak orang tua yang tidak bisa menggunakan media komunikasi berbasis komputer selain telepon (Verbatim FGD I, 41).

Gina memiliki keprihatinan terhadap situasi anak-anak di jaman komunikasi berbasis komputer ini. Dengan memegang BlackBerry, seorang anak dapat menemukan berbagai informasi, termasuk informasi-informasi "yang [sebenarnya] belum saatnya dia terima" (Verbatim FGD IV, 25). Banyak anak sekarang ini sangat fasih menyanyikan lagu-lagu yang liriknya berbahasa orang dewasa. Ini sangat mempengaruhi perkembangan anak, juga cara ia berkomunikasi dengan orang lain, termasuk dengan orangtuanya. Di sini pun muncul masalah norma, yang menurut Gina penting diatasi dengan "kontrol" oleh orangtua/ orang dewasa.

Isu-isu ini mempertegas satu hal, yakni: inti komunikasi berbasis komputer adalah manusia, bukan teknologi. Manusia berkomunikasi (berbasis komputer) tidak sekadar demi memanfaatkan inovasi-inovasi teknologi komunikasi. Manusia berkomunikasi karena ia memiliki kecenderungan alamiah untuk menjangkau segala sesuatu di luar dirinya; membuka diri dan membangun persekutuan dengan yang lain. Di dalam keterbukaan terhadap yang lain ini-lah manusia menjadi sungguh manusia (Benedict XVI, 2009). Seorang teolog Yunani Ortodoks, John D. Zizioulas menjelaskan hal ini dalam konsep person atau 'pribadi'. Sosok 'pribadi' selalu bergerak ke luar dari dirinya untuk berjumpa dan bersatu dengan 'yang lain', membentuk komunio, persekutuan (Zizioulas, 2006: 13, dst. ).

\section{NILAIKOMUNALDALAMKEHIDUPAN BERIMAN}

Dalam banyak tradisi keagamaan, perjumpaan face-to-face atau perjumpaan langsung merupakan unsur vital untuk membangun persekutuan atau komunitas. Lebih lagi, hidup berkomunitas merupakan bagian dari ungkapan iman. Tradisi ini memang harus berhadapan dengan gaya berkomunikasi berbasis komputer yang justru merelatif-kan peran perjumpaan langsung. Inilah pemikiran yang melatar-belakangi diskusi mengenai pengaruh komunikasi berbasis komputer terhadap nilai komunal komunitas beriman.

Para narasumber terfokus pada penggunaan media komunikasi berbasis komputer. Media komunikasi berbasis komputer digunakan untuk menyebarluaskan berbagai informasi kegiatan komunitas (rapat, ibadat, lomba futsal, dsb.) dan/atau berita-berita penting berkaitan dengan komunitas. Media ini digunakan juga untuk sharing doa, sabda, dan pengalaman iman. Dalam contoh-contoh ini, media komunikasi berbasis komputer tidak menggantikan kehadiran konkret, melainkan mengantar ke perjumpaan langsung antar anggota komunitas.

Dalam contoh lain, media komunikasi berbasis komputer memang dipakai sebagai alternatif kehadiran konkret di dalam komunitas. Ardi (FK), Gina (FK), dan Benny (FE) mengakui bahwa media komunikasi berbasis komputer dapat menolong para pemimpin komunitas mengatasi keterbatasan ruang dan waktu untuk 
menyapa jemaat mereka. Misalnya, seorang pendeta ternama di Indonesia menyediakan video rekaman kotbahnya untuk disebarluaskan melalui televisi dan/atau internet. Dengan cara ini, si pendeta menyapa jemaatnya di semua cabang gerejanya di tanah air. Uskup pun dapat melakukan hal serupa untuk menyampaikan surat gembala ke semua paroki di wilayah keuskupannya. (Verbatim FGD V, 26; Verbatim FGD IV, 53, 54. )

Bila kehadiran konkret si pemimpin ibadat dapat digantikan dengan kehadiran virtual, bagaimana dengan kehadiran umat? Dian (FK), seorang Protestan, berpendapat bahwa kehadiran seorang beriman dalam ibadat komunitasnya sangat bergantung pada kebutuhan imannya. Hanya orang beriman itu sendiri yang tahu kebutuhan rohaninya dan bagaimana cara memenuhi kebutuhannya itu. Beribadat dengan datang ke gereja atau dengan mengikuti acara kebaktian yang ditayangkan di televisi merupakan keputusan atas dasar kebebasan pribadinya (Verbatim FGD IV, 56).

Tetapi bagi Rudy, media komunikasi apa pun tidak dapat membuat alternatif kehadiran konkret umat di dalam ibadat, terutama di dalam Perayaan Ekaristi. Sebagai seorang Katolik, ia menghayati Perayaan Ekaristi sebagai simbol kebersamaan umat yang dibangun hanya dengan perjumpaan langsung (Verbatim FGD I, 43). Rudy memberikan contoh: "[M]isa Paskah pagipagi "kan selalu disiar-in di Indosiar. Ada gak sih yang berlutut [di depan televisi] misalkan disuruh berlutut [oleh imam yang tampil di layar kaca]?" (Verbatim FGD I, 48). Tidak ada jaminan bahwa umat berpartisipasi penuh di dalam Perayaan Ekaristi yang ditayangkan melalui media komunikasi berbasis komputer. Di dalam pandangan ini, bahkan kehadiran konkret imam di tengah-tengah umat tak dapat digantikan oleh media komunikasi apa pun.

Tanggapan-tanggapan ini tidak merepresentasikan keutuhan pandangan mengenai pengaruh komunikasi berbasis komputer terhadap nilai komunal suatu komunitas beriman. Namun, terlihat jelas bahwa nilai komunal suatu komunitas beriman tidak lagi disadari sebagai nilai yang berkorelasi dengan kehadiran personal, kehadiran 'yang lain', dan "sense of connection" (Tubbs and Moss, 2008: 547). Nilai komunal tidak lagi diperhitungkan sebagai bagian dari iman. Aspek komunal dalam kehidupan komunitas beriman disederhanakan menjadi, bahkan diidentikkan dengan mengikuti kegiatan bersama (ibadat/doa) di suatu tempat, pada suatu waktu tertentu. Iman tetap dilihat sebagai urusan privat.

Contoh Perayaan Ekaristi yang diajukan oleh Rudy menjadi pengingat bahwa Gereja Katolik melihat aspek komunal yang kuat dalam liturgi. Komunio dalam liturgi, terutama dalam Perayaan Ekaristi, mengandung makna kesatuan yang melibatkan kehadiran pribadi-pribadi orang-orang beriman dan kehadiran Kristus (Sacrosanctum Concilium, 7). Ketika Perayaan Ekaristi dilihat sebagai sekadar kegiatan bersama, ketidakhadiran akan mendapatkan toleransi sangat besar dari diri sendiri maupun dari anggota komunitas yang lain. Ketika Perayaan Ekaristi dilihat sebagai sekadar kegiatan bersama, kehadiran konkret pun tidak serta merta melibatkan partisipasi pribadi beriman. Hal ini dinyatakan oleh Gina (FK) dalam komentarnya:

[B]anyak yang datang ke gereja tapi juga ga bener-bener jiwanya ada di sana, gitu. Misalnya $[. .$.$] ngobrol sama sebelahnya, [...] atau$ [...] BB-BB-an. Jadi, sebenernya yang datang ke gereja tiap Minggu itu juga bukan berarti orang yang lebih baik dibanding orang yang ga datang ke gereja. (Verbatim FGD IV, 58.)

\section{HARAPAN BAGI DIALOG ANTAR AGAMA?}

Komunitas-komunitas agama memperhitungkan komunikasi berbasis komputer sebagai peluang untuk berkomunikasi secara cepat dengan jangkauan yang sangat luas . Mereka memanfaatkan media komunikasi berbasis komputer untuk mewartakan ajaran-ajaran agama, pertama-tama dan terutama bagi anggota komunitas mereka masing-masing. Situs-situs religius/keagamaan menyemarakkan ruang virtual sejak tahun 2000 (Campbell, 2010: 22-26). Bukan hanya tokoh agama, melainkan setiap orang beriman yang memiliki akses dapat menciptakan website atau weblog (blog), meng-up load clip di YouTube, dan/atau menyebarkan Twitter bermuatan religius. Ana (FPsi) mengakui ruang virtual sebagai tempat ia belajar mengenai makna perayaan Natal dan Paskah, kisah-kisah para kudus, dan berbagai tradisi dalam Gereja Katolik (Verbatim FGD III, 123).

Namun, situs-situs ini merupakan ruangruang terbuka yang memungkinkan 'kunjungan' lintas komunitas. Artinya, informasi mengenai ajaran dan tradisi agama Katolik yang ditemukan oleh Ana, mungkin pula ditemukan/dipelajari 
oleh umat beragama lain. Apakah ini merupakan peluang untuk mengembangkan relasi antar umat beragama di Indonesia?

Beberapa narasumber mengakui ruangruang virtual ini sebagai ruang pertukaran informasi hal-hal keagamaan. Andreas (FKIP), seorang Muslim, mengalami situs-situs religius sebagai ruang untuk mengenal ajaran-ajaran agama-agama lain. Menurutnya, pertukaran infomasi dapat berkembang menjadi diskusi yang "mengarah kepada kebaikan" tanpa "menenggelamkan perbedaan agama masing-masing" (Verbatim FGD II, 84). Lebih dari ini, Elie (FKIP) berpendapat: pertukaran informasi dapat pula membangkitkan kepedulian dan rasa kemanusiaan yang menjadi dasar solidaritas antar umat beragama. Ia memberikan contoh gerakan anti kekerasan di dunia virtual pasca tragedi ledakan bom di sebuah rumah ibadah agama tertentu (Verbatim FGD II, 86).

Pendapat Elie meneguhkan keyakinan narasumber yang lain bahwa dialog antar komunitas beragama di ruang virtual hanya terjadi ketika orang berbicara mengenai isu-isu sosial-kemanusiaan. Sedangkan, agama itu sendiri, menurut Fendy (FT), tetap merupakan topik yang sensitif (Verbatim FGD I, 71). Fendy dan banyak narasumber lain menemukan lebih banyak sindiran dan ejekan di dalam komentar-komentar mengenai tradisi dan ajaran agama di Facebook, Twitter, dan blog. Apalagi, Rudy dan Gina mengingatkan, seseorang dapat hadir tanpa identitas, anonim, di ruang virtual (Verbatim FGD I, 87; Verbatim FGD IV, 84). Sedangkan, Yusi melihat bahwa saling sindir dan saling ejek bersumber dari dan sekaligus melestarikan cap atau pandangan stereotip-negatif yang melekat pada sebuah kelompok agama (Verbatim FGD $5,86)$. Untuk mengubah ruang virtual sebagai ruang sindiri-menyindir menjadi ruang dialog lintas agama, para narasumber mengungkapkan dua syarat yang berkaitan dengan kemampuan intelektual dan kepemimpinan.

Kemampuan intelektual yang memadai, disertai kematangan pribadi merupakan dasar sikap bertanggung jawab dalam mem-posting dan menanggapi berbagai informasi dan komentar mengenai hal-hal keagamaan di dunia virtual. Kemampuan intelektual dan kematangan pribadi juga membantu orang keluar dari fanatisme, kecenderungan kuat untuk melihat diri dan agamanya sebagai yang paling benar. (Verbatim FGD I, 65; Verbatim FGD II, 85). Keduanya perlu dimiliki oleh siapa pun yang menggunakan komunikasi berbasis komputer, termasuk pemimpin agama dan umat (Verbatim FGD I, 74, 76, 85, dst. ; Verbatim FGD V, 90).

Lebih dari ini, pemimpin agama harus pula menjalankan peran-peran sebagai pengawas dan pengontrol jaringan komunikasi berbasis komputer, dan penyaring informasi yang bersikap objektif dan netral (Verbatim FGD I, 97, 102; Verbatim FGD II, 102, 104; Verbatim FGD IV, 75, 82). Timotius (FKIP) dan Tomas (FPsi) menambahkan, demi peran-peran ini, pemimpin agama semestinya menguasai teknologi komunikasi berbasis komputer (Verbatim FGD II, 113; Verbatim FGD III, 226). Menunjukkan kepemimpinan yang tegas tidak berarti menyangkal perkembangan pesat komunikasi berbasis komputer, melainkan mengembangkan kebaikankebaikan yang dibawanya.

Jadi, dalam konteks relasi antar agama pun, komunikasi berbasis komputer bukan hal teknologinya, melainkan hal tindakan orang/ komunitas beriman menentukan penggunaannya untuk membangun relasi/dialog (bdk. Campbell, 2010: 39). Di sinilah pernyataan Kevin patut dijadikan bahan refleksi. Menurut Kevin, relasi antar komunitas beragama semestinya dibangun secara personal melalui perjumpaan real yang intensif. Komunikasi berbasis komputer tidak mendukung hal ini karena ia sendiri kekurangan aspek personal dan bersifat sangat massal (Verbatim FGD I, No. 73).

\section{PENUTUP}

Dalam pandangan orang-orang muda, komunikasi lebih dari sekadar penyampaian informasi. Komunikasi merupakan pembangun relasi dengan diri sendiri (ekspresi diri), sesama, dan Tuhan. Pengertian ini menjadi dasar pandangan mereka terhadap komunikasi berbasis komputer. Dimensi personal dalam komunikasi menjadi esensial dalam pertimbangan pilihan antara kehadiran konkret/perjumpaan langsung dan kehadiran virtual. Ini berlaku dalam konteks relasi antar pribadi, relasi di dalam komunitas agama, dan relasi antar komunitas agama.

\section{Yap Fu Lan}

Lulusan dari THE CATHOLIC THEOLOGICAL UNION, CHICAGO, USA.

Dosen Ilmu Teologi Universitas Atmajaya, Jakarta.Email: yapfulan@atmajaya.ac.id 


\section{CATATAN AKHIR}

1. Pengumpulan data melalui fgd dan pengolahan verbatim dilaksanakan sejak Maret hingga November 2011, dengan melibatkan tiga orang mahasiswa: Brigita Refi, Ariani, dan Andreas Bangun Wijaya sebagai fasilitator fgd dan penyusun verbatim.

2. Bukan nama sebenarnya; demikian juga namanama mahasiswa yang dituliskan di dalam uraian selanjutnya.

\section{KEPUSTAKAAN}

Benedict XVI, 2009, "New Technologies, New Relationships, Promoting a Culture of Respect, Dialgoue, and Friendship," Message of the Holy Father for the 43rd World Communications Day. Vatikan.

http://www. vatican. va/holy_father/benedict_xvi/ messages/communications/documents/ hf_ben-xvi_mes_20090124_43rdworld-communications-day_en. html (diakses pada 20 Desember 2011). , 2012. "Silence and Word: Path of Evangelization," Message of the Holy Father for the 46th World Communications Day. Vatikan.

http://www. vatican. va/holy_father/benedict_xvi/ messages/communications/documents/ hf_ben-xvi_mes_20120124_46thworld-communications-day_en. html (diakses pada 18 Februari 2012).
3. Peneliti pernah menguraikan gagasan serupa mengenai keheningan dan evangelisasi dalam artikel "Silence, The Origin of Evangelization, A Discourse with Max Picard, Raimon Panikkar, and Aloysius Pieris", dalam Jurnal Sekolah Tinggi Filsafat Driyarkara DISKURSUS /2011

Campbell, Heidi A., 2010, When Religion Meets New Media. Abingdon: Routledge.

Hardawiryana, Robert, penerjemah, 1998, Dokumen Konsili Vatikan II. Jakarta: Dokpen KWI-Obor.

Ruben, Brent D., dan Lea P. Stewart, 2006, Commuication and Human Behavior, Fifth Edition. Boston: Pearson Education.

Tubbs, Stewart, dan Sylvia Moss, 2008, Human Communication, Principles and Contexts, Eleventh Edition. New York: McGraw Hill.

Zizioulas, John D., 2006, Communion and Otherness. London-New York: T\&T Clark. 